\title{
GROWTH AND PRODUCTION PERFORMANCES OF CROSSBRED CLIMBING PERCH KOI, Anabas testudineus IN BANGLADESH
}

\author{
A.H.M. Kohinoor*, M.S. Islam, D.A. J ahan, M.M. Khan and M.G. Hussain
}

Received 12 December 2011, Revised 26 February 2012, Accepted 15 June 2012, Published online 30 June 2012

\begin{abstract}
The study was performed for evaluating the growth and production performances of crossbred climbing perch (Anabas testudineus) during August to October 2009. The crossbred groups of fish were produced by crossing between native climbing perch and Thai climbing perch (A. testudineus). Growth and production performances was compared at grow out condition between crossbred groups in the two reciprocal crosses of treatments viz. $\mathrm{T}_{1}$ : Native climbing perch $(+) \times$ Thai climbing perch $(\hat{0})$ and $\mathrm{T}_{2}$ : Thai climbing perch $(+) \times$ Native climbing perch ( $\partial$. At the same time, they were compared also with their respective control $F_{1}$ pure line groups i.e. $T_{3}$ : Native climbing perch $(+$ ) $\times$ Native climbing perch $\left({ }^{\top}\right)$ and $\mathrm{T}_{4}$ : Thai climbing perch $(\uparrow) \times$ Thai climbing perch $\left({ }^{\Uparrow}\right)$. It was evident from the results that among the treatments in grow out system, the highest mean harvesting weight was $69.25 \pm 9.01$ gfound in $\mathrm{T}_{4}$ (Thai climbing perch), which was significantly different $(\mathrm{P}<0.05)$ from all other treatments. Whereas, $\mathrm{T}_{3}$ (native climbing perch) also showed the lowest mean harvesting weight $33.38 \pm 8.74 \mathrm{~g}$ and showed significant differences $(\mathrm{P}<0.05)$ among all the treatments. The mean harvesting weight of both the crossbred groups i.e. $\mathrm{T}_{1}$ and $\mathrm{T}_{2}$ were $50.83 \pm 6.65$ and $59.94 \pm 7.83 \mathrm{~g}$, respectively and these results were statistically insignificant $(\mathrm{P}>0.05)$ between them but significant among all other treatments. The highest $(93.60 \%)$ and lowest $(83.06 \%)$ survival rates were observed in Thai koi $\left(\mathrm{T}_{4}\right)$ and native Koi $\left(\mathrm{T}_{3}\right)$ parental stocks, respectively. Wider variations in terms of productions performances were observed among the treatments, where the gross production of $T_{1}, T_{2}, T_{3}$ and $\mathrm{T}_{4}$ were $2,753 \pm 96.67,3,401 \pm 73.26,1,733 \pm 168.47$ and $4,051 \pm 185 \mathrm{~kg} / \mathrm{ha}$, respectively. The productions obtained from crossbred groups were at intermediate compared to their control pure line groups. Higher FCR mean value was observed in native control line $\left(\mathrm{T}_{3}\right)$, while, lower FCR mean value was observed in Thai control line $\left(\mathrm{T}_{4}\right)$.
\end{abstract}

Keywords: Growth, Crossbred, Climbing Perch Koi

Freshwater Station, Bangladesh Fisheries Research Institute, Mymensingh, Bangladesh

*Corresponding author's email: kohinoor41@gmail.com (A.H.M. Kohinoor)

Reviewed by Dr. Binay Kumar Chakraborty, Matshya Bhabon, Romna, Dhaka, Bangladesh.

\section{Introduction}

Climbing perch Koi (Anabas testudineus) is an important indigenous fish species of Bangladesh. The fish is very popular for its delicious taste and flavour. This species considered as a valuable item of diet for sick and convalescent. According to Saha (1971), the fish contain high values of physiologically available iron and copper essentially needed for hemoglobin synthesis. Once climbing perch was abundantly available in almost all freshwater systems of Bangladesh, however, recently population of this fish has been declining very rapidly. The reasons for such decline are many, such as ecological degradation, indiscriminate fishing, use of pesticides and fertilizers, destruction of habitats, obstruction to breeding migration, management failure, etc. In the face of diminishing natural population of climbing perch-planners, policy makers, aquaculturists, and fisheries biologists are thinking of its cultivation through intensive farming (DOF, 2002).

A substantial number of seasonal water bodies like ponds, ditches, canals etc. are presently lying fallow and not suitable for carp culture. In this context, our endemic koi fish is the promising species for culture in such waters bodies due to the presence of their accessory respiratory organs, which allow them to thrive in waters with low oxygen levels. During the past few years, natural population of these fishes is rapidly decreasing due to lack of scientific management 
and draining out of beels, marshes and similar natural habitat to meet up the excessive market demand and also for the production of paddy and other agricultural crops. Moreover, natural breeding grounds are under continuous destruction due to use of excessive fertilizer, insecticides and pesticides. If this situation continues, these endemic local koi will be endangered in near future. In our country, culture of these species has not yet been flourished. Among various reasons, lack of appropriate technology, paucity of fry and fingerlings, and determination of appropriate stocking density are the major setbacks for its culture in the country. The breeding technology of native Koi (A. testudineus) had successfully been developed in freshwater Station of the Institute (Kohinoor, 1991). But the growth rate is very slow in comparison to Thai Koi A. testudineus. Its slow growth and small size does not favour sustainable production per unit area in a culture system (Kohinoor et al., 2009).

To overcome this situation, another fast growing climbing perch known as Thai koi (Anabas testudineus) has been introduced from Thailand in 2002. This strain has some special characteristics such as faster growth rate, shorter culture period, higher survival rate etc. Seed production of this species through artificial propagation technique has been developed (Kohinoor and Zaher, 2006). Introduced Thai A. testudineus is fast growing, however, it does not taste like Native A. testudineus. Although the Thai A. testudineus is presently used for production purposes by large number of farmers but it is not widely accepted by consumers owing to its lack of taste in comparison to native A. testudineus. The proposed research activities have been addressed with an objective to develop cross bred Koi through crossing between native and Thai Koi (A. testudineus).

\section{Materials and Methods}

Crossbred koi fry were produced through crossing between native Koi and Thai koi. Prior to breeding, 400 native Koi having mean weight $48.24 \pm 3.26 \mathrm{~g}$ were collected from natural sources and reared in a pond $\left(400 \mathrm{~m}^{2}\right)$. While, 500 Thai Koi $(68.20 \pm 4.29 \mathrm{~g})$ were collected from Thailand and reared also in same size pond. Supplementary feed containing 30\% crude proteins were supplied at $4-8 \%$ of estimated body weight in both native and Thai koi. During breeding season (March-May, 2009), four groups of fry were produced through induced breeding. The groups- 1, 2, 3 and 4 were assigned as tretaments- 1, 23 and 4, respectively. These treatments are as follows:

$\mathrm{T}_{1}$ (Group I): Female native koi $(+9) \times$ Male Thai koi $(\stackrel{ }{(})$ $\mathrm{T}_{1}$ (Group II): Female Thai koi $(+) \times$ Male native koi $(\hat{\jmath})$ $\mathrm{T}_{1}$ (Group III): Female native koi $(+$ ) $) \times$ Male native koi $(\precsim)$ $\mathrm{T}_{1}$ (Group IV): Female Thai koi $(+$ ) $\times$ Male Thai koi $(\hat{})$

\section{Production of pure line Thai and native koi fry}

Pure line Thai and native koi fry were produced in the hatchery of Freshwater Station, Bangladesh Fisheries Research Institute (BFRI) through induced breeding propagation.

\section{Grow out sy stem}

\section{Design of experiment}

In this experiment, there were four treatments with three replications. In all the treatment groups, the stocking density was maintained at 62,500 ha $^{-1}$. In this experiment, four earthen ponds were used. Each pond was equally partitioned by bamboo split into three chambers $\left(100 \mathrm{~m}^{2}\right)$. The details of design of experiment are shown in Table 1.

Table 1. Stocking density in the four treatments

\begin{tabular}{|c|c|}
\hline Treatment groups & Stocking density ha $^{-1}$ \\
\hline $\mathrm{T}_{1}$ : Female native koi $(+) \times$ Male Thai koi $\left(0^{\wedge}\right)$ & 62,500 \\
\hline $\mathrm{T}_{2}$ : Female Thai koi $(+) \times$ Male native koi $\left({ }^{\lambda}\right)$ & 62,500 \\
\hline $\mathrm{T}_{3}$ : Female native koi $($ ( $) \times$ Male native koi $(\widehat{ })$ & 62,500 \\
\hline $\mathrm{T}_{4}$ : Female Thai koi $(0) \times$ Male Thai koi $\left({ }^{\lambda}\right)$ & 62,500 \\
\hline
\end{tabular}

\section{Pond preparation}

The ponds were dried and cleaned for weed and unwanted animals. The dried ponds were left exposed to sunlight for seven days and then limed at the rate of $250 \mathrm{~kg} \mathrm{ha}^{-1}$. Five days after liming, underground water was supplied from a deep tube well to the ponds and filled up to the depth of 1 meter. After three days, the ponds were fertilized with cow dung at the rate of 2,000 $\mathrm{kg} \mathrm{ha}^{-1}$.

\section{Fish stocking and management}

The ponds were stocked with fish after five days of fertilization. The initial weights of fry were $1.06 \pm 0.24,104 \pm 0.26,1.09 \pm 0.30$ and $1.13 \pm 0.28$ g, respectively. After stocking, Feeding was done with floating pelted feed containing 30\% crude protein @ 4-10 \% of body weight twice daily. 


\section{Fish sampling}

Sampling was done at 15 days interval and random samples of $50 \mathrm{~A}$. testudineus fry were caught by seine net from all the treatments to assess the growth and health condition for feed adjustment.

\section{Analyses of water quality parameters}

Water samples were collected between 09:00 to 10:00 am at three days intervals of each pond surface to a depth of $20 \mathrm{~cm}$ (Azim et al., 2001). A number of clean $500 \mathrm{ml}$ black bottles marked with pond number and sampling date were used for collection of water samples. The bottles were then brought to the Water Quality and Pond Dynamics Laboratory of Freshwater Station, Bangladesh Fisheries Research Institute. Water temperature $\left({ }^{\circ} \mathrm{C}\right)$ from each pond was recorded at least three spots by using a Celsius thermometer. Water transparency was determined by using a standard Seechi disc of $20 \mathrm{~cm}$. diameter. Dissolved oxygen $(\mathrm{mg} / \mathrm{l})$ and $\mathrm{pH}$ were measured using a digital DO meter (HANNA, model HI 9142) and a direct reading digital $\mathrm{pH}$ meter (HANNA, model HI 9025), respectively. Total alkalinity $(\mathrm{mg} / \mathrm{l})$ was determined titrimetrically according to the standard procedure and methods (APHA, 1992). Ammonia-nitrogen was measured using a high precision HACH Kit (DR 2000).

\section{Harvesting of fish}

After 120 days of rearing, the fish were harvested from all the ponds. Primarily the harvesting of fish was performed by repeated netting using a seine net and final harvesting was done by dewatering the ponds with a submerged low lift pump. During harvest, all fishes were counted and weighed from each pond to assess the survival rate and production

\section{Analysis of experimental data}

Data were analyzed using the statistical package, Statgraphics Version 7. ANOVA was performed on all the dependent variables to find out whether treatments had any significant effect on growth. Duncan's New Multiple Range Test (DMRT) was performed to identify any significant difference among treatment means.

\section{Results}

Detailed results of the study on growth performances, survival rate, fish biomass, water quality parameters and all other aspects as recorded during the period of study are presented.

\section{Water quality parameter}

Mean levels of physicochemical parameters over 120 days of rearing of crossbred and control groups of koi are presented in Table 2.
Temperature is one of the most important physical factors, which influences the physicochemical and biological environment of a water body. The mean values of water temperature of $\mathrm{T}_{1}, \mathrm{~T}_{2}, \mathrm{~T}_{3}$ and $\mathrm{T}_{4}$ were $27.70 \pm 1.32,27.94 \pm 1.67$, $27.98 \pm 1.46$ and $28.19 \pm 1.59^{\circ} \mathrm{C}$. The variations in temperature among the treatment means were found similar $(\mathrm{P}<0.05)$.

Water transparency varied between 26 and 34 $\mathrm{cm}$ when all ponds and sampling times were considered. It varied a little among the treatments with an average of $25.75 \pm 4.75$, $24.83 \pm 4.12,28.58 \pm 3.84$ and $22.91 \pm 4.80 \mathrm{~cm}$ in $T_{1}, T_{2}, T_{3}$ and $T_{4}$, respectively. These readings were not significantly different when compared using ANOVA. Water transparency varied between 18 and $36 \mathrm{~cm}$ when all ponds and sampling times were considered. The water transparency did not show any significant $(\mathrm{P}<0.05)$ difference among the treatment means. The values of transparency some times varied with sampling dates which could be due to differences in abundances of plankton.

The level of $\mathrm{pH}$ varied from 6.89 to $8.11,6.92$ to $8.84,7.04$ to 8.2 .3 and 6.86 to 8.25 in $\mathrm{T}_{1}, \mathrm{~T}_{2}, \mathrm{~T}_{3}$ and $\mathrm{T}_{4}$, respectively. The $\mathrm{pH}$ in all pond water was alkaline throughout the experimental period which might be due to regular application of lime in all the ponds at monthly interval.

The dissolved oxygen contents in the experimental ponds ranged from 4.24 to 6.80 , 4.1 to $6.6,4.11$ to 7.40 and 4.20 to $9.90 \mathrm{mg} \mathrm{L}^{-1}$ in $T_{1}, T_{2}, T_{3}$ and $T_{4}$, respectively, with the mean values of $5.30 \pm 0.69,5.36 \pm 0.65,5.57 \pm 0.95$ and $4.2 \pm 0.69 \mathrm{mg} \mathrm{L}^{-1}$. Comparatively higher level of dissolved oxygen as observed in the experimental ponds appeared to be related to sampling time where the dissolved oxygen was monitored at about 9.00-10.00 am.

Total alkalinity ranged from 85 to 145,92 to 142 , 104 to 162 and 94 to $152 \mathrm{mg} \mathrm{L}^{-1}$ with mean values of $108.83 \pm 13.34,113.25 \pm 14.15,124.95 \pm 13.41$ and $116.54 \pm 15.58 \mathrm{mg} \mathrm{L}^{-1}$ in $\mathrm{T}_{1}, \mathrm{~T}_{2}, \mathrm{~T}_{3}$ and $\mathrm{T}_{4}$, respectively. When the results of all ponds collected over the entire experimental periods were compared, there was no significant difference.

Ammonia-nitrogen is toxic to fish and above a certain level it can cause fish mortality. The range of ammonia-nitrogen was 0.021-0.80, $0.011-0.79,0.015-0.64$ and $0.01-0.99 \mathrm{mg} \mathrm{L}^{-1}$ in treatments-1, 2, 3 and 4, respectively. The highest ammonia-nitrogen value was 0.99 in the month of October in treatment- 4 and the lowest value was 0.011 in the month of August in treatment-3. The differences among treatments were not significant $(P>0.05)$ when compared using ANOVA. 
Table 2. Mean values of water quality parameters in different treatments

\begin{tabular}{lllll}
\hline Water quality parameters & \multicolumn{4}{c}{ Treatment } \\
\cline { 2 - 5 } & \multicolumn{1}{c}{$\mathrm{T}_{1}$} & \multicolumn{1}{c}{$\mathrm{T}_{2}$} & \multicolumn{1}{c}{$\mathrm{T}_{3}$} & \multicolumn{1}{c}{$\mathrm{T}_{4}$} \\
\hline Temperature $\left({ }^{\circ} \mathrm{C}\right)$ & $27.70 \pm 1.32$ & $27.94 \pm 1.67$ & $27.98 \pm 1.96$ & $28.19 \pm 1.82$ \\
Transparency $(\mathrm{cm})$ & $25.75 \pm 4.75$ & $24.83 \pm 4.12$ & $28.58 \pm 3.84$ & $22.91 \pm 4.80$ \\
pH & 6.89 to 8.11 & 6.92 to 8.84 & 7.04 to 8.23 & 6.86 to 8.25 \\
Dissolved oxygen $\left(\mathrm{mg} \mathrm{L}^{-1}\right)$ & $5.30 \pm 0.69$ & $5.36 \pm 0.65$ & $5.57 \pm 0.95$ & $4.2 \pm 0.69$ \\
Total alkalinity $\left(\mathrm{mg} \mathrm{L}^{-1}\right)$ & $108.83 \pm 13.34$ & $113.25 \pm 14.15$ & $124.95 \pm 13.41$ & $116.54 \pm 15.58$ \\
$\mathrm{NH}_{3}-\mathrm{N}\left(\mathrm{mg} \mathrm{L}^{-1}\right)$ & $0.29 \pm 0.15$ & $0.26 \pm 0.13$ & $0.19 \pm 0.11$ & $0.34 \pm 0.17$ \\
\hline
\end{tabular}

\section{Growth and production}

Details of stocking, growth, survival, harvesting and production of koi under four treatments are presented in Table 3. It was evident from the results that among the treatment groups in growout system, the highest harvesting mean weight $69.25 \pm 11.35 \mathrm{~g}$ was found in $\mathrm{T}_{4}$ (Thai climbing perch) which was significantly different $(\mathrm{P}<0.05)$ from all other treatments. Whereas, $\mathrm{T}_{3}$ (native climbing perch) also showed the lowest harvesting mean weight $(33.38 \pm 8.7 \mathrm{~g})$, which was significantly different $(\mathrm{P}<0.05)$ from all other treatments. The harvesting mean weight of both the crossbred groups i.e. $T_{1}$ : Native koi $(+$ ) $\times$ Thai koi $\left({ }^{\Uparrow}\right)$ and $T_{2}$ : Thai koi $($ ( $) \times$ Native koi $\left({ }^{\Uparrow}\right)$ were $50.83 \pm 6.65$ and $59.94 \pm 7.83 \mathrm{~g}$, respectively and these results were not statistically significant $(\mathrm{P}>0.05)$ between them. The growth of crossbred was at intermediate between the pure line Thai koi and native koi. It is remarkable that, the growth rate of both crossbred groups were significantly higher $(\mathrm{P}<0.05)$ than that of pure line native koi, while growth rate of both crossbred group of koi showed significantly lower $(\mathrm{P}<0.05)$ than that of pure line Thai stock. The growth patterns of koi in different months of different treatments are shown in Figure 1, where a clear distinguishable difference in weight was observed in every month among the treatments.

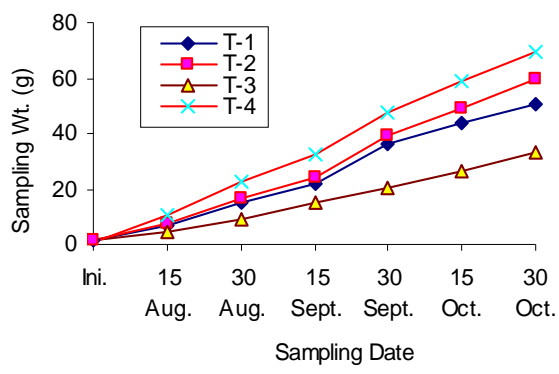

Fig. 1: Sampling Wt. (g) Koi in different treatments
The mean survival rate of koi was found to vary in different treatments. The highest (93.6\%) and lowest (83.06\%) survivals were observed in Thai koi $\left(\mathrm{T}_{4}\right)$ and native Koi $\left(\mathrm{T}_{3}\right)$ parental stocks, respectively. The differences among the treatment means of survivals were found to be insignificant $(\mathrm{P}>0.05)$. The survival of cross bred group i.e. $\mathrm{T}_{1}$ and $\mathrm{T}_{2}$ were 86.67 and $90.80 \%$, respectively, where the difference between the treatments are apparent but were not statistically significant. The survival rate of Thai Koi $\left(\mathrm{T}_{4}\right)$ showed significant differences with cross bred groups and native koi i.e. $T_{1}, T_{2}$ and $T_{3}$.

The specific growth rate (SGR) of koi at different treatments was observed to be 3.23, 3.40, 2.90 and 3.52 for $T_{1}, T_{2}, T_{3}$ and $T_{4}$, respectively. The SGR of native koi in $T_{3}$ was significantly $(P \varangle 0.05)$ different from $T_{1}, T_{2}$ and $T_{4}$, whereas, $\mathrm{T}_{1}$ and $\mathrm{T}_{2}$ did not show any significant difference $(\mathrm{P}>0.05)$ between them.

However, the gross production of $\mathrm{T}_{1}, \mathrm{~T}_{2}, \mathrm{~T}_{3}$ and $\mathrm{T}_{4}$ were $2,753 \pm 96.67,3,401 \pm 73.26,1,733 \pm 168.47$ and $4,051 \pm 185 \mathrm{~kg} / \mathrm{ha}$, respectively. Wider variations in terms of production performances were observed among the treatments. These results when tested statistically, showed significant differences among the treatments. The highest and lowest production was observed in $\mathrm{T}_{4}$ (Thai koi) and $\mathrm{T}_{3}$ (native koi), respectively. The production obtained from cross bred groups of koi showed higher values over native koi, but Thai koi showed higher production over crossbred koi. The production variation between crossbred groups was not significant $(\mathrm{P}>0.05)$. Production of cross bred groups showed 58-96\% higher than that of native koi while 16-33\% less than Thai koi. 
Table 3. Mean weight, survival and production of Koi under different treatments

\begin{tabular}{lccccccc}
\hline Treatment & $\begin{array}{c}\text { Stocking } \\
\text { Density ha-1 }\end{array}$ & $\begin{array}{c}\text { Mean initial } \\
\text { Wt. (g) }\end{array}$ & $\begin{array}{c}\text { Mean } \\
\text { Harvesting } \\
\text { Wt. (g) }\end{array}$ & $\begin{array}{c}\text { Mean } \\
\text { survival } \\
(\%)\end{array}$ & $\begin{array}{c}\text { Mean } \\
\text { FCR }\end{array}$ & $\begin{array}{c}\text { Mean } \\
\text { SGR (\%) }\end{array}$ & $\begin{array}{c}\text { Mean } \\
\text { Production } \\
\left(\mathrm{kg} \mathrm{ha}^{-1}\right)\end{array}$ \\
\hline $\mathrm{T}_{1}$ & 62,500 & $1.06 \pm 0.24$ & $50.83 \pm 6.65^{\mathrm{b}}$ & $86.67 \mathrm{~b}$ & $3.35^{\mathrm{c}}$ & $3.23^{\mathrm{b}}$ & $2,753 \pm 96.67 \mathrm{~b}$ \\
$\mathrm{~T}_{2}$ & 62,500 & $1.04 \pm 0.26$ & $59.94 \pm 7.83^{\mathrm{b}}$ & $90.80^{\mathrm{b}}$ & $3.20^{\mathrm{c}}$ & $3.40^{\mathrm{b}}$ & $3,401 \pm 73.26^{\mathrm{b}}$ \\
$\mathrm{T}_{3}$ & 62,500 & $1.09 \pm 0.30$ & $33.38 \pm 8.74^{\mathrm{d}}$ & $83.06^{\mathrm{c}}$ & $4.25^{\mathrm{a}}$ & $2.90^{\mathrm{c}}$ & $1,733 \pm 168.47$ \\
$\mathrm{~T}_{4}$ & 62,500 & $1.13 \pm 0.28$ & $69.25 \pm 9.01^{\mathrm{a}}$ & $93.60^{\mathrm{a}}$ & $2.90^{\mathrm{b}}$ & $3.52^{\mathrm{a}}$ & $4,051 \pm 185^{\mathrm{a}}$
\end{tabular}

* Dissimilar superscript indicates significant difference at $5 \%$ level of probability

\section{Discussion}

All the water quality parameters of the experimental ponds were found to be within the acceptable ranges for aquaculture and there was no abrupt change in any parameter of the pond water. In this experiment, the variations in water temperature among the treatment means were found similar and were within the suitable range of growth of fish in tropical ponds (Rahman et al., 1982; Roy et al., 2002; Begum et al., 2003, Kohinoor et al., 2007; Mondol et al., 2010). Boyd (1982) reported that the range of water temperature from 26.06 to $31.97^{\circ} \mathrm{C}$ is suitable for fish culture. Normally, the transparency value was low in this experiment because usually koi did not effectively consume plankton (Nargis and Hossain, 1987; Singh and Samual, 1981). Boyd (1982) also recommended a transparency between $15-40 \mathrm{~cm}$ as appropriate for fish culture. The $\mathrm{pH}$ in all pond water was alkaline throughout the experimental period which might be due to regular application of lime in all the ponds at monthly interval. According to Swingle (1967), $\mathrm{pH}$ from 6.5 to 9.0 is suitable for pond fish culture and $\mathrm{pH}$ more than 9.5 is unsuitable. Different authors have reported a wide variations in $\mathrm{pH}$ from 7.18 to 7.24 (Kohinoor et al., 1998), 7.03 to 9.03 (Roy et al., 2002), 6.8 to 8.20 (Begum et al., 2003) and 7.50 to 8.20 (Chakraborty et al., 2005) in fertilized fish ponds and found the ranges to be productive.

Rahman et al. (1982) measured dissolved oxygen range of 3.8 to $10.7 \mathrm{mg} \mathrm{L}^{-1}$ from a lake situated at Mymensingh. Wahab et al. (1994) recorded dissolved oxygen values ranging from 5.10 to 7.15 mg L-1, while Kohinoor et al. (2007) recorded dissolved oxygen values ranging from 4.12 to 6.80 mg L ${ }^{-1}$. In another study, Mondol et al. (2010) also recorded dissolved oxygen ranging from 6.51 to $6.65 \mathrm{mg} \mathrm{L}^{-1}$ during their experiment in the pond of Bangladesh Agricultural University Campus, Mymensingh. The variations in total alkalinity in all the treatments were found in productive range for aquaculture ponds (Boyd, 1982; Wahab et al., 1995; Kohinoor et al., 1998 and Kohinoor, 2009). Dewan et al. (1991) recorded total ammonia- nitrogen $\left(\mathrm{NH}_{3}-\mathrm{N}\right)$ values of 0.50 to $6.20 \mathrm{mg} \mathrm{L}^{-1}$, which was less than the present study. Ahmed (1993) found $\mathrm{NH}_{3}-\mathrm{N}$ values 0.03 to $0.04 \mathrm{mg} \mathrm{L}^{-1}$, while Azim et al. (1995) recorded mean total ammonia-nitrogen of $0.10 \mathrm{mg} \mathrm{L}^{-1}$. Mondol et al. (2010) recorded total ammonia- nitrogen range from 0.098 to $0.167 \mathrm{mg} \mathrm{L}^{-1}$ in the research ponds of Bangladesh Agricultural University Mymensingh.

The productivity of Thai koi was much more higher than native and cross bred groups. While, the production of crossbred groups were higher than native koi. The mean harvesting weight and survival rate of Thai Koi was higher than all other treatments. For this reason, Thai Koi showed highest production among the treatments. While the mean harvesting weight and survival of crossbred groups exhibited higher values than native koi. Therefore, the production of crossbred groups also higher than native koi but lower than that of Thai koi. The survival rate of all treatments was fairly high. Among the treatments, the lowest survival was observed in native koi $\left(\mathrm{T}_{3}\right)$. The main factors that might have attributed to the high survival were the proper stocking of healthy seed, freedom from predation, favourable ecological conditions (physicochemical factors) and also proper feeding etc. High survival rate of climbing perch was reported by many authors (Rao, 1971, Kohinoor et al., 2007, 2009 and Kim Van Van and Vo Qui Hean, 2009). These indicated that climbing perch is an excellent candidate for aquaculture perhaps more so than other culture species.

Thakur and Das (1986) reported that Koi (Anabas testudineus) production was $1,800 \mathrm{~kg}$ ha $^{-1}$ in India by applying supplementary feed (rice bran, mustard oil cake and fish meal) with the stocking density of 60,000 ha-1 in 170 days. They also stated that by applying the above feed, achieved $702 \mathrm{~kg} \mathrm{ha}^{-1}$ over a period of 330 days, where the stocking density was 1,25,000 ha- ${ }^{-1}$. Earlier study conducted by Akhteruzzaman (1988) evaluated the production potentials of native koi (Anabas testudineus) in monoculture 
management at the density of $16,000 \mathrm{ha}^{-1}$ and obtained a production of $450 \mathrm{~kg} \mathrm{ha}^{-1}$ in five months rearing with supplementary feed consisted of rice bran (50\%), mustard oil cake (30\%) and fish meal (20\%).

In a trial conducted by Kohinoor et al. (2007) investigated on the effects of stocking density on the growth and production of Thai Koi (Anabas testudineus) in Freshwater Station, Bangladesh Fisheries Research Institute at three stocking densities (50,000 to 1,25,000 ha-1) by applying supplementary feed (35\% crude protein). They observed growth was increased in the treatment with lower stocking density and obtained production 6480 to $6617 \mathrm{~kg} \mathrm{ha}^{-1}$ in 150 days culture period.

Kohinoor et al. (2009) assessed the production potentials of native koi (Anabas testudineus) at different stocking densities (50,000 to 62,250 ha $^{-1)}$ in Freshwater Station, Bangladesh Fisheries Research Institute, Mymensingh. They found the highest total net yield of 1,916 ha-1 over a period of 5 months culture period by applying supplementary feed containing 35\% crude protein. The production obtained in the cross bred group was lower than these mentioned results of Thai koi by different authors. Whereas, the production of native Koi was lower over cross bred groups these also mentioned by different authors (Akhteruzzaman, 1988; Thakur and Das, 1986; Kohinoor et al., 2009).

\section{Conclusion}

In native koi, yellowish colour found in the abdomen region, which also observed to some extent in the crossbred group $\left(\mathrm{T}_{1}\right)$. Body shapes of cross bred koi $\left(\mathrm{T}_{1}\right)$ was more or less same as native koi, while the production of both the two groups of crossbred Koi were comparatively higher over native koi. Organoleptic testing of the four groups of koi revealed that the crossbred koi showed superior taste performances compared to Thai koi. Therefore, in terms of taste in associated with production values, crossbred koi can be a good culture species in Aquaculture Avenue.

\section{References}

Akhteruzzaman, M. 1988. A study on the production of koi fish (Anabas testudineus) under semi-intensive culture system. J. Zool., 3: 39-43.

APHA. 1992. Standard Methods for the Examination of Water and Waste Water. American Public Health Association, Washington DC.

Azim, M.E., Talukder, G.S., Wahab, M.A., Haque, M.M. and Haq, M.S. 1995. Effect of liming and maintenance of total hardness levels on fish production in fertilized ponds. Progress. Agric., 6 (2): 7-14.

Azim, M.E., Wahab, M.A., Van Dam, A.A., Beveridge, M.C.M., Huisman, E.A. and Verdegem, M.C.J. 2001. Optimization of stocking ratios of two Indian major carps, rohu (Labeo rohita Ham.) and catla (Catla catla Ham.) in a periphyton based aquaculture system. Aquaculture, 203:3349.

Begum, M., Hossain, M.Y., Wahab, M.A. and Kohinoor, A.H.M. 2003. Effects of isophosphorus fertilizers on water quality and biological productivity in fish pond. J. Aqua. Trop., 18 (1): 1-12.

Boyd, C.E. 1982. Water quality management for pond fish culture. Elsevier Sci. Publ. CO. Amsterdam-Oxford- NewYork. 318 p.

Chakraborty, B.K., Miah, M.I., Mirza, M.J.A. and Habib, M.A.B. 2005. Growth, yield and returns to Puntius sarana (Hamilton) Sharpunti, in Bangladesh under semi intensive aquaculture. Asian Fisheries Science, 18: 307-322.

Dewan, S., Wahab, M.A., Beveridge, M.C.M., Rahman, M.H. and Sarker, B.K. 1991. Food selection, electivity and dietary overlap among planktivorous Chinese and Indian major carps fry and fingerlings grown in extensively managed, rain-fed ponds in Bangladesh. J. Aquaculture and Fisheries Management, 22: 277-294.

DOF. 2002. Fisheries fortnight souvenir. Department of Fisheries, Dhaka, Bangladesh, 87p.

Kim Van van and Vo Qui Hean. 2009. Intensive nursing climbing perch (Anabas testudineus (in hapas using pellet feed at different protein levels. J. Sci. Dev. (Eng. Tsn.), 7: 239-242.

Kohinoor, A.H.M and Zaher, M. 2006. Breeding of exotic koi (Anabas testudineus) at BFRI. Fisheries Newsletter, 14 (1): 1-2.

Kohinoor, A.H.M., Akhteruzzaman, M., Hussain, M.G. and Shah, M.S. 1991. Observations on the induced breeding of koi fish, Anabas testudineus (Bloch) in Bangladesh. Bangladesh J. Fish., 14(1-2): 73-77.

Kohinoor, A.H.M., Islam, A.K.M.S., Jahan, D.A., Zaher, M. and Hussain, M.G. 2007. Monoculture of climbing perch, Thai koi, Anabas testudineus (Bloch) under different stocking densities at on-farm management. Bangladesh J. Fish. Res., 11(2): 173-180.

Kohinoor, A.H.M., Islam, M.L., Wahab, M.A. and Thilsted, S.H. 1998. Effect of mola (Amblypharyngodon mola Ham.) on the growth and production of carps in polyculture. Bangladesh J. Fish. Res., 2(2): 119-126. 
Kohinoor, A.H.M., Jahan, D.A., Khan, M.M., Ahmed, S.U. and Hussain, M.G. 2009. Culture potentials of climbing perch, Anabas testudineus (Bloch) under different stocking densities at semi-intensive management. Bangladesh J . Fish. Res., 13(2): 115-120.

Mondal, M.N., Shahin, J., Wahab, M.A., Asaduzzaman, M. and Yang, Y. 2010. Comparison between cage and pond production of Thai Climbing Perch (Anabas testudineus) and Tilapia (Oreochromis niloticus) under three management systems. J. Bangladesh Agril. Univ., 8(2): 313-322.

Rahman, M.S., Chowdhury, M.Y., Haque, A.K.M.A. and Haq, M.S. 1982. Limnological studies of four ponds. Bangladesh J. Fish., 25(1-2): 25-35.

Rao, S.V. 1971. The Indian climbing perch, Koi. Science Report, 8 (2): 63.

Roy, N.C., Kohinoor, A.H.M., Wahab, M.A. and Thilsted, S.H. 2002. Evaluation of performance of Carp-SIS Polyculture technology in the rural farmer's pond. Asian Fisheries Science, 15: 41-50.
Saha, K.C. 1971. Fisheries of West Bengal. West Bengal Government Press, Alipore, West Bengal, India.

Shingh, K.P and Samuel, P. 1981. Food and feeding habits and gut contents of Anabas testudineus (Bloch). Matsya., 7: 96-97.

Swingle, H.S. 1967. Standardization of chemical analyses for waters and pond muds. FAO Fish. Rep., 4(4): 397-421.

Thakur, N.K and Das, P. 1986. Synopsis of biological data on Koi, Anabas testudineus (Bloch). Bulletin No. 40, Central Inland Fisheries research Institute, Barrackpore, India. 47p.

Wahab, M.A., Ahmed, ZF., Islam, M.A. and Rahmatullah, S.M. 1995. Effect of introduction of common carp, Cyprinus carpio (L), of the pond ecology and growth of fish in polyculture. Aquaculture Research, 26: 619-628.

Wahab. M.A., Ahmed, ZF., Haq, M.S. and Begum, M. 1994. Compatibility of silver carp in the poly culture of cyprinid fishes. Progress. Agric., 5 (2): 221-227. 